\title{
SISTEM INFORMASI GEOGRAFIS UNTUK PENDATAAN SEBARAN SATWA LANGKA DI INDONESIA
}

\author{
Fery Sofian Efendi ${ }^{1)}$, Abidatul Izzah $^{2)}$, dan Sudarmaji ${ }^{3)}$ \\ 1,2,3)Teknik Informatika, Politeknik Kediri \\ Jl. Mayor Bismo No. 27, Mojoroto, Kediri, Jawa Timur \\ e-mail: fery.sofian@ gmail.com ${ }^{1)}$, abidatul.izzah90@ gmail.com ${ }^{2)}$, sudarmajikdr@gmail.com $^{3)}$
}

\begin{abstract}
ABSTRAK
Indonesia adalah negara yang memiliki banyak variasi satwa yang tersebar di seluruh kepulauan dan memiliki keanekaragaman yang berbeda-beda. Namun, pada kenyataannya, kekayaan ini tidak diimbangi dengan kepedulian dan keingintahuan masyarakat mengenai keberadaan dan kelestariannya. Hal ini dapat disebabkan karena media yang menampung informasi satwa ini sangatlah sedikit. Jika hal ini dibiarkan berlarut-larut, maka lama kelamaan keberadaan satwa tersebut akan menjadi punah. Dengan demikian diperlukan sebuah media yang mampu merekam data sebaran satwa yang di lindungi di Indonesia. Data satwa ini dapat berupa nama ilmiah dan lokasi satwa tersebut dipelihara. Oleh karena itu penelitian ini mengimplementasikan Sistem Informasi Geografis (SIG) berbasis Google API sebagai media yang mampu mendata sebaran satwa yang dilindungi oleh pemerintah Indonesia. Adanya SIG yang dapat merepresentasikan sebaran data satwa dalam bentuk peta dapat memudahkan pengaksesan informasi dan menampilkan lokasi mengenai sebaran satwa langka di Indonesia. SIG yang dibangun dalam penelitian ini memiliki tiga user yaitu administrator, lembaga konservasi yang berperan sebagai kontributor, dan masyarakat sebagai pengunjung web. Fitur yang dimiliki oleh SIG ini antara lain adalah fitur pencarian informasi satwa, pencarian lokasi satwa langka, dan penanda lokasi pada map.
\end{abstract}

Kata kunci: Google API, Satwa Langka, Sistem Informasi Geografis.

ABSTRACT

Indonesia is a country that has a lot of variety of animals. In fact, they are scattered throughout the islands and has a big diversity in them. However, the wildlife animals were not a concern of the public at all. It can be caused by media that holds the information of this animal is not well. If this is allowed to drag on, then over time the number of these animals will become extinct. Because of this, it is needed to build a media that capable to recording data or information about the distribution of wildlife in Indonesia. This information can be their scientific name and where they lived. Therefore, this study implements a Geographic Information System (GIS) based Google API as a media that is able to record the distribution of species protected by the Indonesian government. GIS can presents the distribution of animals in maps. The SIG can be used by three users, that is administrator, conservation organizations as a contributor, and society as a web visitor. The features that we can use are searching wildlife information, searching location of endangered species, and marking location on the maps.

Keywords: Geographic Information Systems, Google APIs, Rare Animals.

\section{Pendahuluan}

I NDONESIA adalah negara tropis yang kaya akan berbagai sumber daya alam salah satunya adalah satwa. Satwa langka di Indonesia tersebar di seluruh kepulauan dan memiliki keanekaragaman yang berbeda-beda. Satwa langka adalah hewan yang hampir terancam punah dari keberadaannya akibat dari keserakahan manusia yang melakukan penebangan hutan secara liar yang merupakan habitat dan ekosistem dari hewan tersebut. Selain itu, pembakaran hutan baik yang disebabkan oleh pemanasan global maupun adanya kesengajaan dari manusia itu sendiri dengan tujuan untuk memperluas area pertanian ataupun memperluas wilayah pemukiman juga dapat menyebabkan kepunahan satwa tersebut. Di sisi lain, banyaknya hiasan-hiasan yang menggunakan tulang belulang dari hewan dengan harga yang lebih mahal, menjadikan perburuan dan perdagangan hewan menjadi semakin meningkat tanpa mengindahkan punahnya keberadaan hewan tersebut. Hal-hal demikianlah yang menyebabkan angka kepunahan satwa semakin besar.

Pada lampiran Peraturan Pemerintah Nomor 7 Tahun 1999 [1], telah ditetapkan jenis-jenis satwa yang dilindungi. Jenis-jenis satwa yang ditetapkan sebagai jenis satwa yang dilindungi karena satwa tersebut memiliki nilai ekonomis yang tinggi dan jumlah persebarannya pada saat ini makin terancam kepunahan sehingga satwa tersebut akan menjadi langka.

Pemeliharaan satwa yang seharusnya dilindungi oleh pemerintah dan masyarakat ini tidak diimbangi dengan kepedulian dan keingintahuan masyarakat mengenai keberadaan dan kelestariannya. Hal ini dikarenakan informasi yang didapat oleh masyarakat tentang satwa sangat sedikit. Pada era ini, penyebaran informasi melalui buku ataupun media tulis lainnya masih belum cukup dalam meningkatkan rasa keingintahuan masyarakat. Kurangnya interaksi dan daya tarik menjadi nilai minus didalamnya. Jika informasi-informasi mengenai satwa yang ada di Indonesia itu tidak diketahui oleh masyarakat maka lama kelamaan keberadaan satwa tersebut akan menjadi langka. Dengan demikian diperlukan sebuah media yang mampu merekam data sebaran satwa yang dilindungi di Indonesia. Data satwa ini dapat berupa nama ilmiah dan lokasi satwa tersebut 
dipelihara. Oleh karena itu penelitian ini akan mengimplementasikan Sistem Informasi Geografis (SIG) berbasis Google API sebagai media yang bertujuan untuk mendata sebaran satwa yang dilindungi oleh pemerintah Indonesia. SIG merupakan sistem informasi yang khusus yang mengelola data yang memiliki informasi spasial (letak geografis). Adanya SIG yang dapat merepresentasikan sebaran data satwa dalam bentuk peta dapat membantu dan memudahkan pengaksesan informasi dan lokasi mengenai satwa di Indonesia.

\section{SISTEM INFORMASI GEOGRAFIS DAN GOOGLE API}

Sistem Informasi Geografis (SIG) atau Geographic Information System (GIS) menurut [2] adalah sebuah sistem informasi yang khusus mengelola data yang memiliki informasi spasial misalnya letak geografis suatu lokasi. Penggunaan SIG banyak diimplementasikan pada kasus yang memerlukan informasi lokasi. Pada [3], teknologi GIS digunakan untuk manajemen pariwisata demi meningkatkan ekonomi pariwisata suatu daerah, GIS yang dikembangkan untuk menyediakan informasi tempat wisata kepada turis disebut dengan Travel Geographic Information System (TGIS). TGIS dikembangkan atas dasar database informasi geografis pariwisata berfungsi untuk mengumpulkan data, menampilkan data-data terkait pariwisata seperti transportasi, akomodasi, tempat hiburan, pasar, dan karakteristik budaya daerah tersebut agar dapat memberikan layanan yang akurat dan nyaman untuk memenuhi kebutuhan yang berbeda dari setiap pengguna. Selain itu, implementasi WebGIS untuk kepariwisataan juga telah diterapkan di Kabupaten Sumba Timur. Dalam implementasinya pun WebGIS dapat memberikan informasi posisi daerah wisata secara lebih detail kepada pengunjung/wisatawan karena sampai mengandung informasi tingkat desa [4]. Tidak hanya itu, pemanfaatan SIG juga dapat digunakan untuk menganalisis genangan air hujan [5]. Dalam hal ini diterapan teknik penginderaan jauh, dengan menggunakan citra satelit Landsat ETM 7 sebagai alat bantu. Lebih lanjut, teknologi informasi digunakan untuk pengolahan data elektronik dengan SIG dan bantuan perangkat lunak tertentu (software pengolah citra/ER Mapper maupun software SIG/AutoCad, MapInfo, ArcView).

Secara umum, penerapan SIG erat kaitannya dengan penggunaan Google API karena dalam pembuatan aplikasi SIG bisa dikatakan bahwa Google API merupakan bagian dan framework yang digunakan. Google menyediakan berbagai Application Programming Interface (API) yang sangat berguna bagi pengembang web maupun aplikasi desktop untuk memanfaatkan berbagai fitur yang disediakan oleh Google. API secara sederhana bisa diartikan sebagai kode program yang merupakan antarmuka atau penghubung antara aplikasi atau web yang kita buat dengan fungsi-fungsi yang dikerjakan [6]. Google API dapat dipelajari langsung melalui Google Code. Terdapat banyak API yang disediakan oleh Google, beberapa diantaranya adalah Language API (untuk memanfaatkan fitur translation yang dimiliki Google), Earth API (untuk memanfatkan fitur yang ada pada Google Earth), Maps API (untuk memanfaatkan fitur yang ada pada Google Maps), Search API (untuk memanfaatkan fitur pencarian pada Google Search), Visualization API (membuat grafik maupun chart Google API).

\section{Metode PENELITIAN}

\section{A. Analisa Kebutuhan}

Analisa kebutuhan sistem bertujuan untuk mengidentifikasi kebutuhan hardware, software dan bahan yang akan digunakan dalam mendukung terbangunnya sistem serta fitur yang akan diimplementasikan dalam SIG. Analisis ini diperlukan sebagai dasar bagi tahapan perancangan sistem dan untuk mengamati bagaimana sistem akan berjalan. Dalam proses pembuatan SIG Satwa ini, dibutuhkan informasi mengenai satwa yang ada di Indonesia dan juga mencakup satwa yang dilindungi sesuai undang-undang. Data-data satwa dalam SIG ini diambil dari kontributor yaitu lembaga konsevasi atau kebun binatang yang memberikan data satwanya di aplikasi ini.

Pengguna atau user pada aplikasi data satwa langka yang ada di Indonesia ini terdiri dari administrator, kontributor, dan pengunjung. User admin memiliki hak akses penuh dalam pengelolaan aplikasi data satwa ini, admin dapat melakukan penambahan dan edit data satwa, kategori satwa, provinsi dan pulau penyebaran satwa. Selain itu admin juga bisa memanajemen user yaitu menambah dan menonaktifkan user. User di sini bisa juga berarti admin lain atau kontributor. Berbeda dengan user admin, user kontributor memiliki hak akses menambah data satwa yang ada di aplikasi ini, dan melakukan modifikasi hanya sebatas data satwa yang telah ditambahkannya sendiri. Pada prakteknya, kontributor diperankan oleh lembaga konservasi. Sedangkan user pengunjung hanya mempunyai hak akses untuk melihat dan mencari data satwa yang ada di aplikasi ini. User pengunjung ini diperankan oleh masyarakat yeng mengakses SIG.

Analisa kebutuhan selanjutnya adalah analisa non-fungsional yang mencakup kebutuhan perangkat lunak yang digunakan untuk membangun SIG. Perangkat lunak yang dibutuhkan dalam membangun SIG data satwa ini adalah Sistem Operasi Windows 7 Ultimate, Apache dan MySQL server, Macromedia Dreamweaver, SQLyog yang digunakan untuk pengelolaan database, dan browser Google Chrome. 


\section{B. Perancangan Sistem}

Perancangan pembuatan SIG Satwa Langka ini dimulai dengan merancang arsitektur sistem. Dari analisa kebutuhan yang dilakukan sebelumnya, diperoleh informasi bahwa penggunaan aplikasi memiliki hubungan antara admin, pengunjung/masyarakat dan anggota/kontributor. Admin mengelola aplikasi dengan menambah, mengubah dan mengahapus data dari satwa langka, admin juga bisa menambah, mengubah dan menghapus data kontributor yang ada di aplikasi ini. Sebagai Kontributor di aplikasi data satwa ini bisa mencari dan mempublikasi data-data satwa langka melalui media sosial (Facebook), dan kontributor bisa menambahkan data satwa langka yang ada di tempat konservasi yang dikelolanya dan mungkin saja data satwa tersebut belum ada di aplikasi data satwa ini. Untuk pengunjung/masyarakat bisa melihat informasi mengenai satwa langka dan mempublikasikanya/share ke media sosial, kemudian bisa juga mencari satwa langka berdasarkan pulau, provinsi, atau dengan mengunakan pencarian per kategori satwa dan kata kunci sehingga di pencarian data satwa lebih maksimal. Dengan demikian, arsitektur SIG Satwa Langka Indonesia dapat ditunjukkan pada Gambar 1.

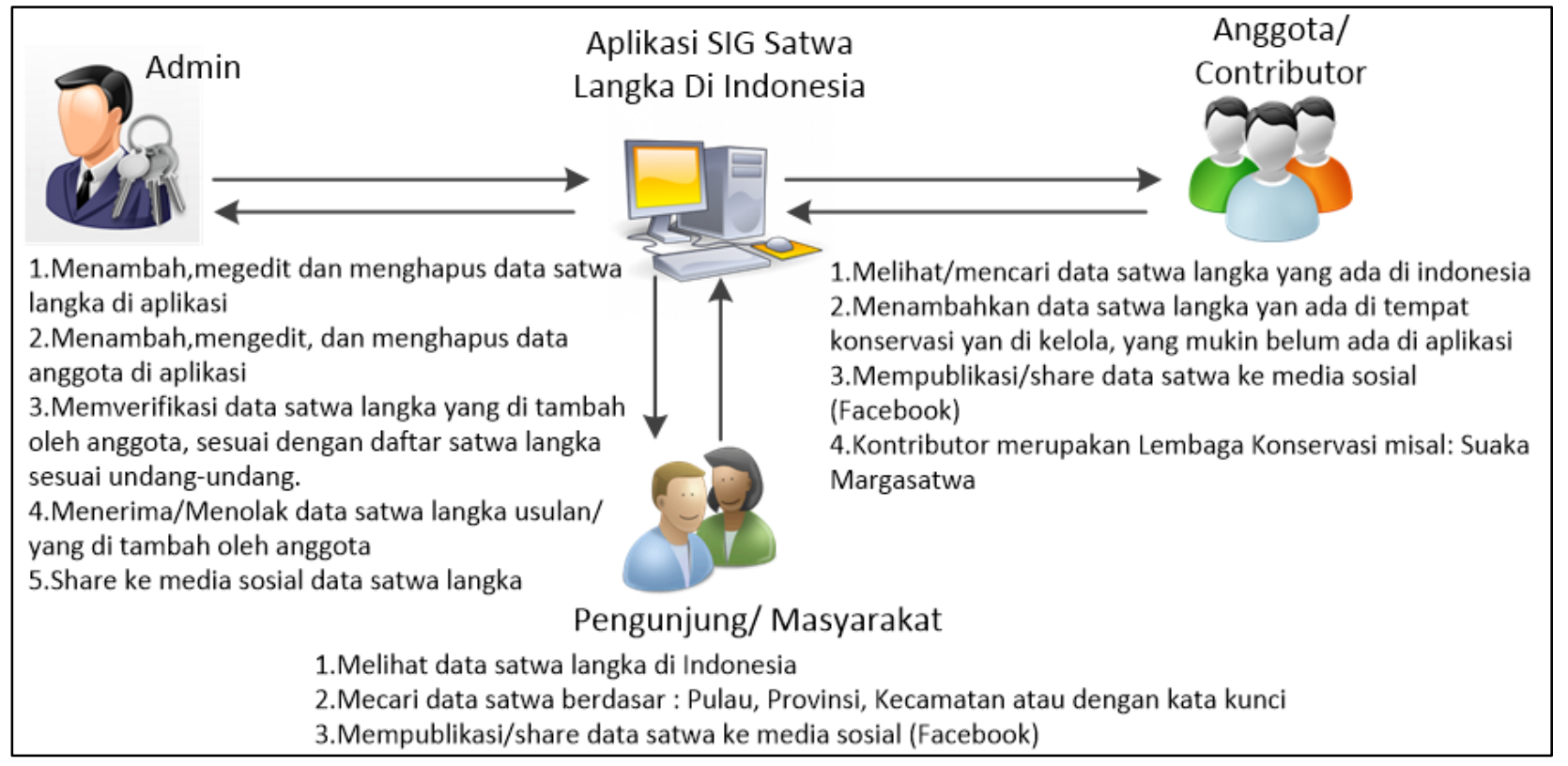

Gambar 1. Arsitektur Sistem Informasi Geografis Satwa Langka

Setelah merancang arsitektur sistem, disusunlah diagram konteks yang merupakan level tertinggi dari Data Flow Diagram (DFD). DFD adalah diagram yang menggambarkan secara luas tentang seluruh inputoutput dalam sistem informasi geografis ini [7]. Diagram konteks yang dibangun seperti yang digambarkan pada Gambar 2.

Gambar 2 diatas merupakan proses diagram konteks yang menjelaskan proses berjalannya admin, kontributor dan masyarakat di dalam SIG data satwa secara umum. Untuk admin mempunyai user dan password untuk login selain itu tugas admin disini untuk mengolah data satwa, data kategori, data lokasi, dan data yang dibutuhkan lainnya, sedangkan untuk kontributor hampir sama hanya saja hak aksesnya sebatas menambhakan data satwa saja. Dan masyarakat hanya bisa melihat dan mencari data satwa.

Selanjutnya perancangan basis data SIG diwujudkan dengan penyusunan Entity Relationship Diagram (ERD). ERD menunjukan informasi yang dibuat, disimpan dan digunakan dalam sebuah sistem aplikasi. Selain itu ERD juga digunakan untuk menunjukan aturan-aturan alur dari basis data yang ada diimplementasikan ke aplikasi tersebut. Secara umum ERD ini juga dapat digunakan untuk memodelkan kebutuhan data dari suatu organisasi, biasanya oleh system analys dalam tahap analisis persyaratan proyek pengembangan sistem [8]. Pada ERD di penelitian ini dijelaskan proses kinerja SIG data satwa, di mana admin dapat mengelola banyak data satwa dari semua jenis kategori satwa yang diproses pada aplikasi data satwa. Selain itu admin juga mengelola users, manajemen file, manajemen users dan mengatur identitas website aplikasi data satwa ini dan juga dapat mengelola identitas pada bagian users.

\section{HaSil dan PEMbahasan}

\section{A. Pendataan Satwa pada Sistem Informasi Geografis (GIS)}

Pendataan satwa yang mengandung informasi satwa dan letak geografis dilakukan oleh pihak kontributor seperti lembaga konservasi atau kebun binatang. Pada proses input data satwa pada SIG data satwa, 
diharuskan mengisi form isian yang telah disediakan yang terdiri dari judul (nama) satwa, kategori satwa, pulau, status konservasi satwa, foto satwa, dan deskripsi mengenai satwa tersebut. Form informasi satwa yang kemudian dirangkum oleh SIG dapat dilihat pada Gambar 3. Selanjutnya untuk menampilkan marker penyebaran satwa tersebut maka pilih semua lokasi provinsi di mana satwa tersebut berada. Proses pendataan sebaran lokasi satwa yang dimasukkan dapat dilihat pada Gambar 4.

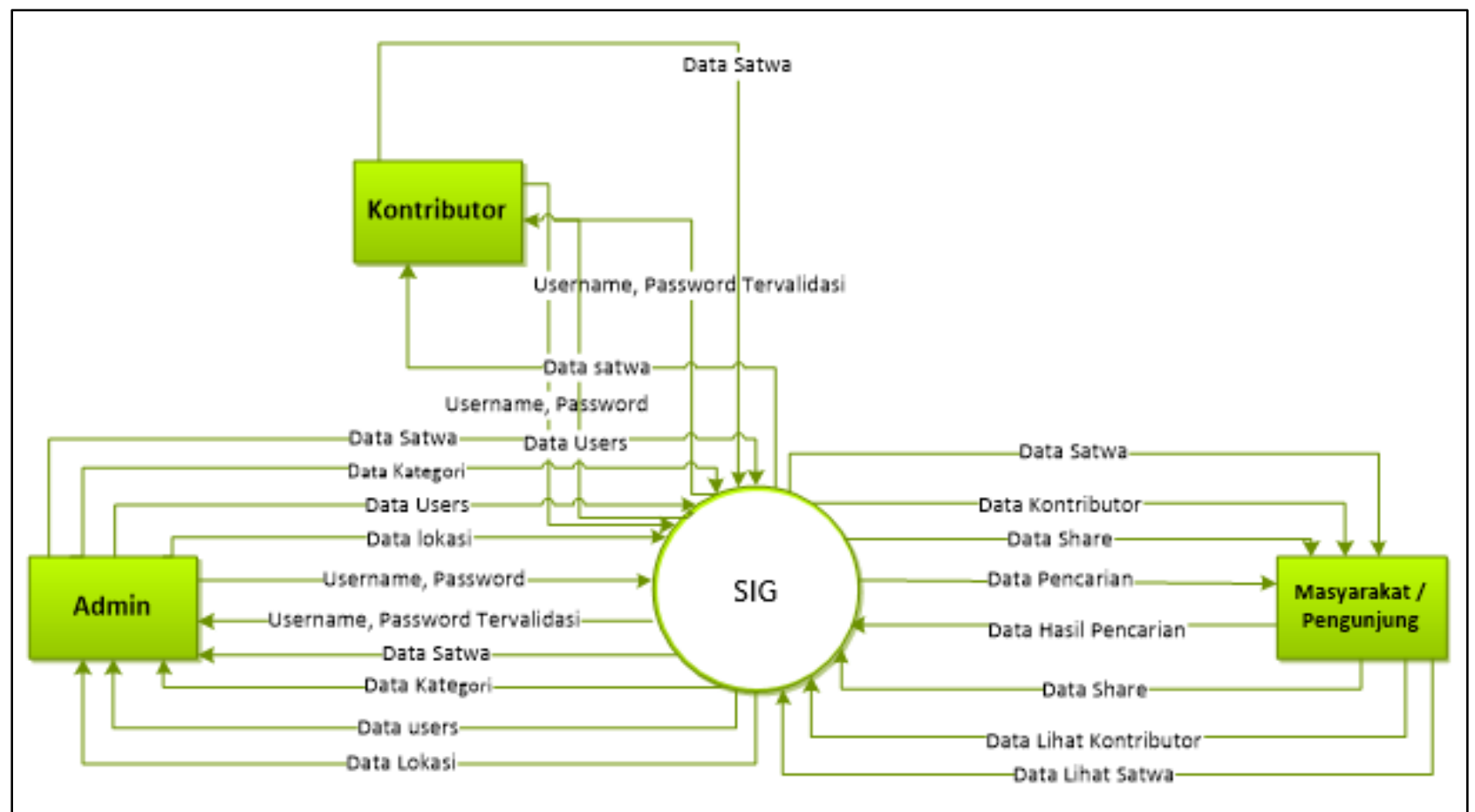

Gambar 2. Diagram Konteks

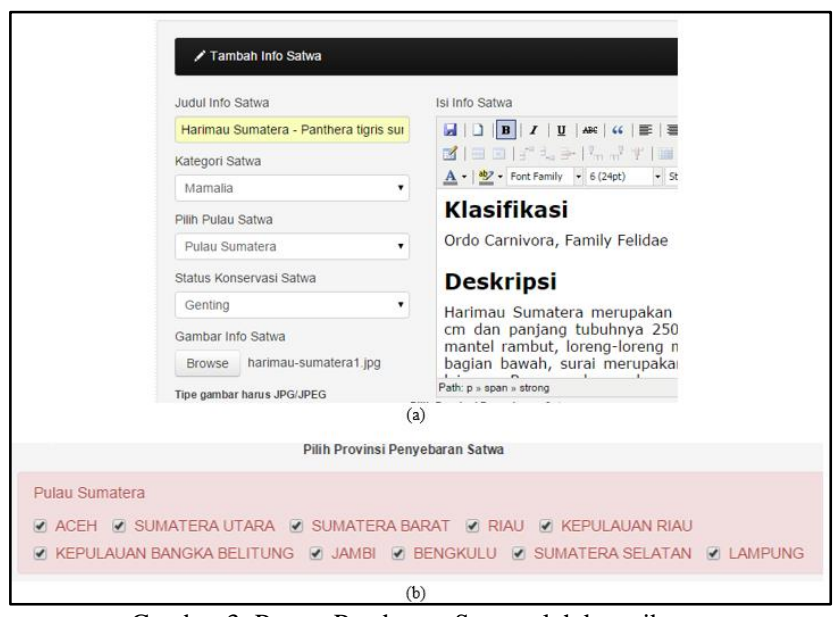

Gambar 3. Proses Pendataan Satwa oleh kontributor

SIG data satwa ini menggunakan peta dari Google Maps untuk menentukan lokasi di mana tempat satwa langka berada. Peta yang ada pada SIG data satwa ini adalah peta statik yang menampilkan marker sesuai lokasi penyebaran satwa. Hasil sebaran lokasi satwa yang dimasukkan berdasarkan pilihan provinsi ini dijadikan sebagai icon marker pada SIG data satwa ini. Misalnya Gambar 4 menunjukkan tampilan hasil dari pemilihan provinsi yang ditempati oleh Harimau Sumatera. Lokasi satwa pada peta ditandai dengan marker berupa icon.

\section{B. Implementasi SIG pada Sebaran Satwa}

Implementasi merupakan tahap pengembangan rancangan menjadi kode program. Bagian utama implementasi adalah penjabaran dari rancangan aplikasi yang sudah dibuat menjadi menjadi sebuah SIG berbasis web yang diimplementasikan dalam kode program atau syntax bahasa pemrograman PHP dan menggunakan CSS Framework Bootstrap. SIG yang telah dibangun memiliki tampilan awal yang mempunyai menu koleksi satwa dan pencarian satwa. Lebih lanjut, tampilan antar muka awal SIG ini dapat dilihat pada 
Gambar 5. Selanjutnya pada menu pencarian, user dapat untuk mencari lokasi satwa secara geografis dengan menampilkannya pada peta. Titik peta dengan penanda merupakan titik lokasi di mana satwa yang dicari berada. Sebagai contoh pencarian satwa dengan nama ilmiah Buceros Rhinoceros ditampilkan oleh SIG seperti pada Gambar 6.

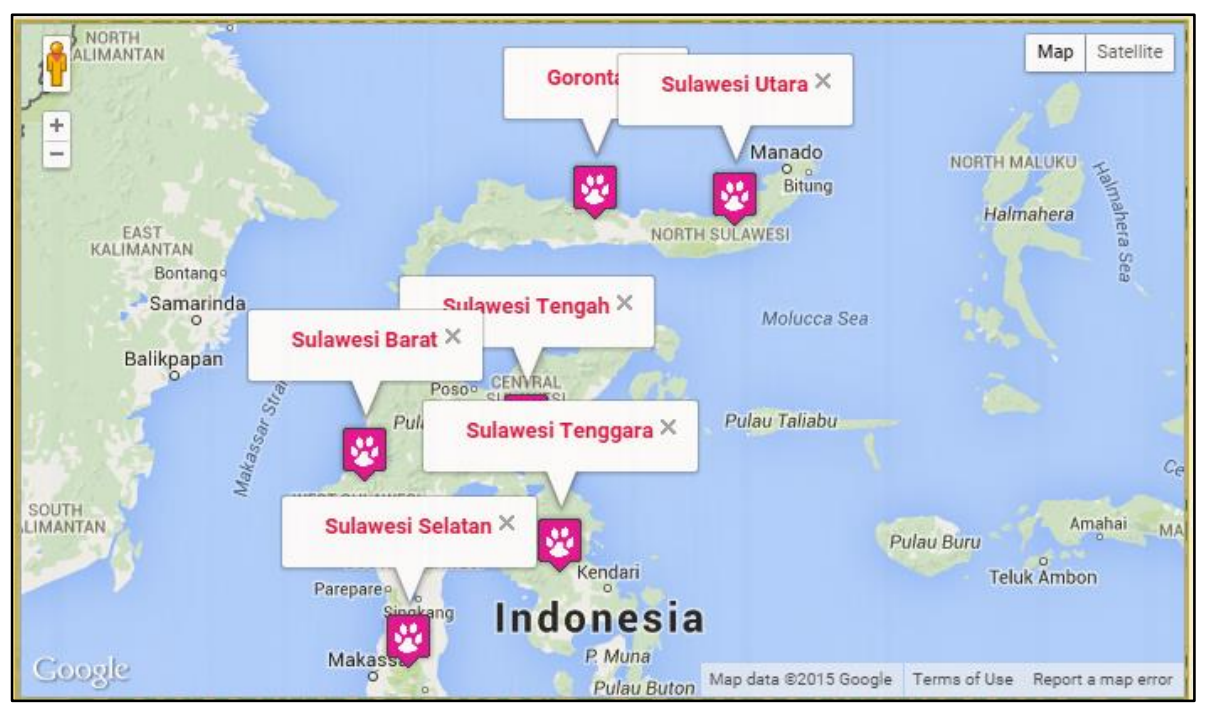

Gambar 4. Tampilan Sebaran Lokasi Harimau Sumatera

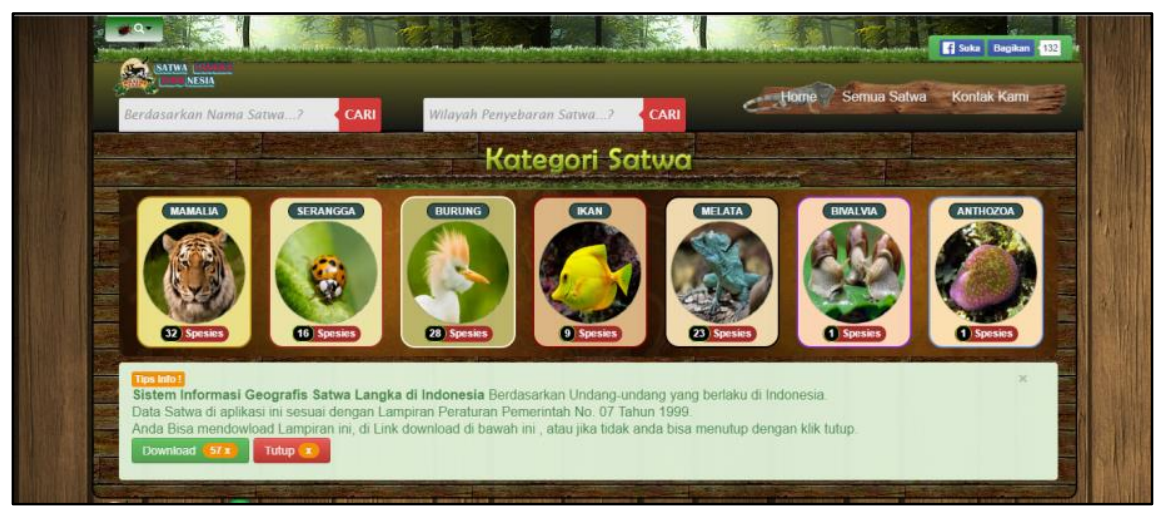

Gambar 5. Tampilan Awal Sistem Informasi Geografis Satwa Langka di Indonesia

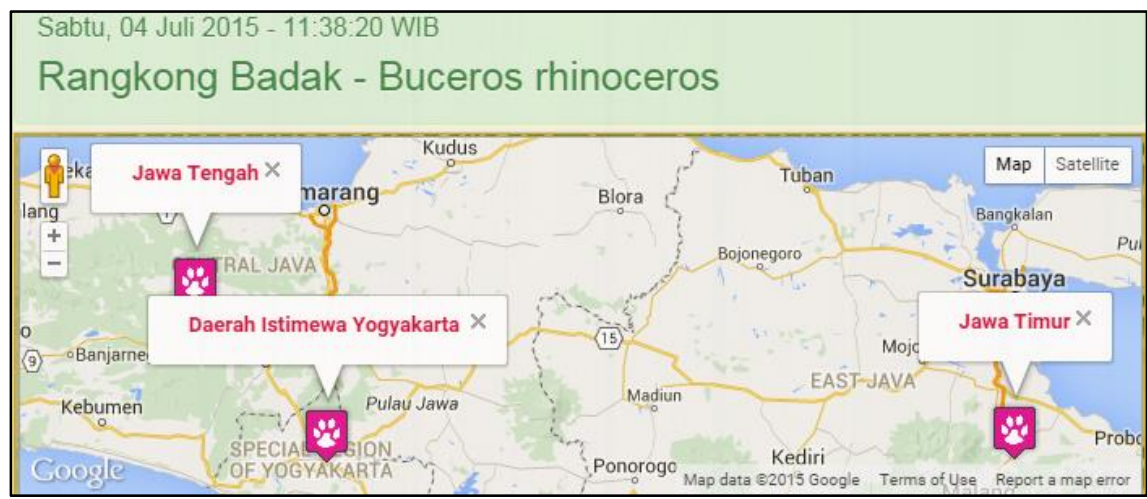

Gambar 6. Hasil Pencarian Sebaran Hewan Buceros Rhinoceros di Indonesia

\section{KESIMPULAN}

Sistem Informasi Geografis (SIG) atau Geographic Information System (GIS) adalah sebuah sistem informasi yang khusus mengelola data yang memiliki informasi spasial misalnya letak geografis suatu lokasi. SIG yang merangkum data satwa langka ini dapat membantu masyarakat dalam memberikan informasi mengenai satwa langka di Indonesia yang dilindungi oleh undang-undang. SIG data satwa ini memberikan informasi data satwa ke dalam bentuk peta dan berbasis web. SIG ini dapat diakses oleh tiga user yaitu administrator, lembaga konservasi yang berperan sebagai kontributor, dan masyarakat sebagai pengunjung web. Fitur yang dimiliki oleh SIG ini antara lain adalah fitur pencarian informasi satwa, pencarian lokasi satwa langka, dan penanda lokasi pada map. Data satwa pada SIG ini dapat berasal dari lembaga konservasi dan 
kebun binatang. Selanjutnya pada SIG ini perlu adanya kerjasama yang luas dari berbagai lembaga konservasi satwa atau kebun binatang, sehingga SIG ini benar-benar bisa menjadi aplikasi yang menjadi sumber rujukan yang valid, dan dapat dipertanggung jawabkan kebenaran atas data-data satwa yang ada pada aplikasi data satwa ini.

\section{Daftar Pustaka}

[1] R. Indonesia, "Peraturan Pemerintah No. 7 Tahun 1999 Tentang : Pengawetan Jenis Tumbuhan Dan Satwa," Menteri Negara Sekretaris Negara Republik Indonesia, Jakarta, 1999.

[2] E. Prahasta, Sistem Informasi Geografis - Konsep-Konsep Dasar (Perspektif Geodesi \& Geomatika), Bandung: INFORMATIKA, 2009.

[3] W. Wei, "Research on the Application of Geographic Information System in Tourism Management," in 2011 International Conference of Environmental Science and Engineering, 1104-1109, 2012.

[4] A. R. Tanaamah dan R. Wardoyo, "Perancangan Dan Implementasi Webgis Pariwisata Kabupaten Sumba Timur," JURNAL INFORMATIKA, vol. 9, no. 2, pp. 150-158, 2008.

[5] S. S. Sayogo, S. W. Mudjonarko dan F. Hardaningrum, "Pemanfaatan Sistem Informasi Geografis Untuk Menganalisis Genangan Air Hujan,” NEUTRON, vol. 9, no. 2, pp. 43-56, 2009.

[6] A. M. Pelupessy, Y. D. Y. Rindengan dan P. D. K. Manembu, "Aplikasi Pemetaan Bangunan Berizin Di Kota Manado,” E-journal Teknik Informatika, vol. 7, no. 1, pp. 1-6, 2016.

[7] R. S. Pressman, Software Engineering: A Practitioners Approach, New: McGraw-Hill, 2010.

[8] M. Brady and J. Loonam, "Exploring the use of entity-relationship diagramming as a technique to support grounded theory inquiry," Qualitative Research in Organizations and Management, vol. 5, no. 3, pp. 224237, 2010. 